\title{
Significance of the Egyptian Crocodile on the Roman Imperial Coinage
}

Wessam Fekry Ibrahim Moussa*

Faculty of Tourism and Hotels, Matrouh University, Egypt

\section{ARTICLE INFO}

Keywords:

Sobek

Crocodile

Egypt

Roman Coinage.

\begin{abstract}
No other creature in ancient Egypt was perhaps as feared, revered and frequently depicted as the crocodile. It was one of the first animals to be early portrayed. It also appeared in ancient texts from the Old Kingdom onwards to symbolize the conflict between good and evil. It was mainly worshipped as Sobek, regarded as both a protector and a demon. This is because there were two types of crocodiles, represented in arts, both lived in Egypt. The Crocodylus Suchus and Crocodylus Niloticus. One of them was considered totally sacred, yet the other one was hated and even eaten by others. The Ptolemaic kings paid great attention to the crocodile cult, for the Romans it was the regular symbol of Egypt and its fertile Nile, especially on coins. This study analyzes some selected coins to assess the various representations of the Egyptian crocodile on coins produced during the Roman Imperial. The findings of the research analysis will highlight the significance of the crocodile as a subject sometimes appeared in the field of numismatic studies, to make it possible to answer some questions concerning interpretations and issues related to its various representations on the Roman coinage.
\end{abstract}

C2021 Faculty of Tourism and Hotels, Fayoum University All rights reserved

\section{Introduction}

The crocodile is an ancient emblem of both cultural and scientific interest. It usually illustrates the great civilizations of Nile River valley. For the ancient Egyptians it was sometimes a target of religious worship and in other cases a source of terror The idea of Egypt evoked powerful creative responses throughout much of Roman history, ranging from admiration to apprehension. Numerous depictions of places, individuals and gods were generated by Roman visual and material culture that either imply Egyptian origins or relate to Roman vision of Egypt. However, the meanings of these representations, images, objects, and their values are still unclear. In antiquity, identical images in different contexts or to different audiences may mean very different concepts. Therefore, the meaning of many Roman images of Egypt avoids reduction to any single interpretation, remaining subject to review, renegotiation, reinterpretation and redefinition according to the variable circumstances

Crocodiles were just as dangerous and horrifying to ancient peoples as they are to us nowadays. For the Romans, the crocodile was most popular as the symbol of Egypt, its depiction on Roman coins was largely related to that territory. In doing so, the study investigates the appearance of the figure of the crocodile on Roman and Roman provincial coinage. It also offers a brief overview of the place of the crocodile in Egyptian culture up to the

\footnotetext{
${ }^{*}$ Contact Wessam Fekry Ibrahim Moussa at: wfekry@ mau.edu.eg
} 
Roman period and then a catalogue of fifteen coins with a crocodile image that reflect some religious remarks or revive particular political ideas related to the land of Egypt.

\section{1 objective of the study}

The main objective of this research is to investigate the various representations of the Egyptian crocodile on coins produced during the Roman Imperial Period, other objectives will contribute to:

- Identify the first appearance of a crocodile on coins

- coins as a material culture generated a representation of a creature that evokes the Egyptian heritage

- Assess the significance of those coins which issued within a specific part of the wide empire for special reasons

- Introduce other scholars to the recent interpretations' issues concerning the various representations of the crocodile on Roman coinage

\section{Literature review}

There were many cults in ancient Egypt involving various deities associated with both domestic and wild animals. One of the most charming cults based on an animal god is the ancient Egyptian crocodile cult. The ancient Egyptians worshiped the

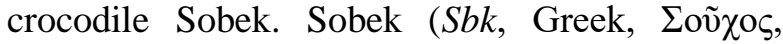
Suchus) was an ancient Egyptian God who is distinguished by his complicated nature, depicted either as a Crocodile or as a crocodile-headed man (Bagnall, 2013).

The crocodile, as well as other species adopted by the Egyptians related to kingship and religion, was a symbol of a particular natural environment with which the Egyptians had to figure out how to deal with (Zecchi, 2010). Crocodiles were associated with the Nile, its fertility and with royal and military power (Bagnall, 2013). As a wild creature, crocodiles are powerful animals, they can live both in the water and on the land, they are also capable of hiding just below the muddy surface of the water, nearly invisible, to attack suddenly (Nizar, et al., 2018). Some accounts showed him as aggressive, evil and hyper-sexed god (Crump, 2021). He was revered as a protector from the dangers of both the real aggressive human-eating crocodiles and the Nile River (Crump, 2021).

Zecchi, depending on the interpretation of a scene on seal impression from tomb 414 of Tarkhan (fig.
1) where many crocodiles are represented on coils accompanying a crocodile on a standard with probably two feathers projecting from its back, concluded that the formation of the crocodile divinity likely dated back to the end of Naqada III in the Fayyum region, Crocodilopolis then, Arsinoë, as the local god of Shedet (Zecchi, 2010). In about 50 BC, Diodorus recorded that Shedet was established by king Menes in gratitude to the crocodile that carried him across Lake Moeris when his own hunting dogs attacked him (Diodorus, I.89).

Limbs" conforming his identification with Osiris (Zecchi, 2010), or from sbk3 he, "who impregnates" (Murray, 1957) to refer to the crocodile's prolificacy (Zecchi, 2010).

Sobek also appeared in the Pyramid Religious Texts of the Old Kingdom (Bresciani, 2005), but he came to popularity during the Middle Kingdom and became the royal god of the twelfth and thirteenth dynasties, who had their capitals in Fayum (Galuzina, 2016). Sobek was associated with other Egyptian main Gods as; Re, Horus, Osiris and Hapi (Galuzina, 2016) that might reflect his significant position in the pantheon of Egypt. Among his titles Sbk $n b$ lord of: strife, $h 3 t$, the river banks, $w d b w$, magnificence in the great place, $f 3 w ~ m$ st wrt (Zecchi, 2010).

The Ptolemaic and Roman periods witnessed a religious development of the crocodile cult. Sobek became a universal deity; Kom Ombo became as another major cult center in addition to that of Fayyum (Bagnall, 2013).

The crocodile God Sobek and his different forms, notably, have been favored by the Ptolemaic dynasty. This prominence may have partly resulted from the vital role, according to Diodorus, played by the Nile crocodiles in the victory of Ptolemy I over Perdiccas (Diodorus, 18.35.5), thereby confirming his possession of Egypt (Draycott, 2012). The story begins when Ptolemy I seized the corpse of Alexander the Great and took it to Egypt in 322 B.C. In response, the man of blood, Perdiccas, who wished to usurp and rule other commanders' authorities by force (Diodorus. 18. 33.3), invaded Egypt and during his attempt to cross the Nile, much of his army were devoured by the crocodiles and other Nile River animals (Diodorus, 18.35.5). Including this story in the writings of Diodorus Siculus refers to its circulation during the $1^{\text {st }}$ century B.C and could indicate the importance of the crocodile since the 
early beginning of the Ptolemaic dynasty as well as paying attention to the difficulties that other forces would face if they tried to invade Egypt.

The endured prestige of the crocodile, during the Ptolemaic period and tributes to him, attained greater prominence through both the establishment of more dedicated cultic centers, and the intensive effort to make him the subject of religious believes (Zecchi, 2010).

During the Graeco-Roman era, the Fayum region was the major center of Sobek's worship and witnessed the religious development of crocodile cult in the area (Manning, 2003). According to classical writers, priests paid much attention to crocodiles, they bred them in temples dedicated to Sobek and often ornamented them with finery.

Strabo, during his journey up to the Nile within the late $1^{\text {st }}$ century B.C., observed a contradictory disposition towards the crocodile among the Egyptians, as it was sometime a target of religious worship and in other cases a source of terror. He (Strabo. Book 17.1.38) wrote about how a tamed crocodile called Suchus was worshipped by the inhabitants of the city of Arsinoë, Crocodilopolis. This tamed crocodile is fed with cake, meat and drinks a mixture of milk honey which strangers who come to see it always offer (Strabo. Book 17.1.38)

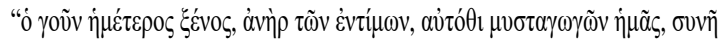

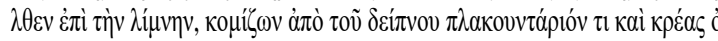

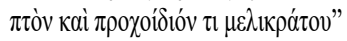

Prior to Strabo, Herodotus in the fourth century BC wrote that a kind of sacred crocodile was looked after in sanctuaries and ornamented with bracelets and golden earrings, fed with particular foods and offerings. After death, theses crocodiles were mummified and buried in sacred coffins (Herodotus, Book 2.69.2). Herodotus stated that the Egyptian called their crocodile as " $\chi \dot{\alpha} \mu \psi \alpha$ " khampsae, it was named crocodile "кроко́ $\delta \varepsilon \imath \lambda о \varsigma$ " by the Ionians who resemble it with the lizard (Herodotus, Book 2.69.2).

Herodotus and Strabo writings indicated the great emphasis on the attention paid to crocodiles by the ancient Egyptians. Molcho suggests that the finding of numerous eggs and young animals in crocodile cemeteries in Fayum proved that it was an ideal breeding area of crocodiles (Molcho, 2014).

Though the crocodile was revered in many ancient Egyptian cities, including, Thebes, Crocodilopolis or Arsinoe, Ombos, Coptos, etc. in other cities it was considered as a harmful and dangerous creature, and treated as such by their residents. Herodotus said that around Elephantine, crocodiles were not sacred, they were eaten. Strabo also mentioned that higher up the Nile at the town of Tentyra, Dendera, the crocodile was utterly hated and considered the most " $\varepsilon \chi \theta 1 \sigma \tau \circ \varsigma$ " "hateful" of all animals (Strabo. 17.1).

From the literature, we can conclude that there are two types of crocodiles, one of them is more docile, easier to be caught and tamed, the other one was more harmful. This observation was confirmed in 1807 by Étienne Geoffroy Saint-Hilaire who gathered a diverse collection of animal mummies including ibises, cats, shrews, and crocodiles throughout the Napoleonic Expedition to Egypt, 1798-1801. He discovered differences between the skulls of a mummified crocodile and those of Nile crocodile and named this species (Crocodylus Suchus) (Saint-Hilaire, 1807), which is the West African Crocodile (Grigg, 2015, Vliet, 2020). He probably borrowed the name from the Greek word

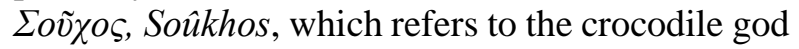
Sobek.

In 2003, Schmitz stated that the Crocodylus Suchus of Hilaire was a valid species (Schmitz et al., 2003). This was confirmed by other studies in 2011 and 2015 (Hekkala et al., 2011, Cunningham, 2015). As Evon Hekkala and her colleagues of Fordham University, New York, who proved that there are two species of Nile crocodiles found in Africa. One is the famed Nile crocodile (Crocodylus Niloticus) which is found within East and Southern Africa. The second one (Crocodylus Suchus) is distributed in West and Central Africa. Hekkala and her team DNA tests, on all Egyptian specimens and mummified sacred crocodiles, revealed that all sampled crocodiles belonged to the second species (Hekkala et al., 2011).

This means that the Egyptian priests recognized the difference long ago and intended to choose the more tractable crocodiles, the sacred Sobek, to keep them in temples and utilize them in the religious ceremonies. On the other hand, the harmful and aggressive ones were treated as enemies.

\subsection{Roman Coinage}

Prior to the third century B.C., the Romans seemed to have no coinage of their own (Hingley, 2004). They used rough bronze, Aes Rude (fig. 2), as a currency, which were of no definite weight or form and had to be weighed and measured for each 
transaction (Lomas, 2018). Later, a more advanced rectangular bars bearing designs forming currency, known as Aes Signatum, came into use in central Italy (Sear, 2014).

The earliest coinage tradition appeared, probably, due to the Romans expansions and their contact with the Greeks (Metcalf, 2012). By 269 B.C., the true coinage likely appeared. There were circular bronze cast coins (Aes Grave), labeled with their values (Britannica, 1997). From 217 B.C., with the silver denarius lunching, an entirely coinage Roman system existed (Burns, 2013). The measurement value was the bronze as, with a weight of one pound (Britannica, 1997), and the silver denarius was equal to ten asses (Potter, 2019).

The Denarius was the Republic and Empire's standard coin (Ermatinger, 2018). Until the late years of the Republic, Roman gold coins were rare and even bronze coinage was issued infrequently (Bland \& Loriot, 2010). It is Augustus who restored the coinage of Aes. From his reign on, the Imperial coins, developed progressively by Augustus successors, were issued in gold, silver, bronze, copper, and orichalcum (Sutherland, 2018). Actually, the various depictions and representations on the obverse and reverse of those coins provided us with invaluable source of cultural material that will always be a subject to study and review

\subsubsection{The early appearance}

After the Roman conquest of Egypt in $30 \mathrm{BC}$, Octavian minted a series of gold and silver coins to commemorate his victory portraying him, on the obverse, facing right, sometimes left, with a crocodile and the legend AEGVPT CAPTA on the reverse. The silver versions were denarii issued in 28 B.C. in Italy and in the Eastern Mediterranean (Sutherland, 2018). A year later, these denarii were followed by a small series of gold aurei with almost same obverse and reverse styles (fig. 4). Both coins honored Octavian primely as son of the divine Julius Caesar to ensure his authority politically and on a religious level. Since this time, Octavian had adopted the name Augustus to mark the beginning of his long rule as the first Emperor of Rome (Bunson, 2014, Sutherland, 2018).

Before the Octavian versions, coins with a representation of crocodile appeared on a coin for the first time in about 37 B.C (fig. 3). They were issued in Crete and Cyrenaica by an official who stroked bronze coins with a crocodile on the obverse and a ship's prow and signed with CRAS or KPA $\Sigma$ on reverse (Robinson, 1927). Scholars (Stevenson, 1889, Svoronos, 1904) identified him as Publius Canidius Crassus, a closed general to Mark Antony (Stevenson, 1889), but most likely he was Marcus Licinius Crassus (Draycott, 2012). More probably, they were produced in Crete and Cyrenaica to commemorate Mark Atony's dedication of these territories to his daughter Cleopatra Selene (Vogeikoff-Brogan, 2015). Draycott, interestingly, argued that the crocodile was specifically selected for Cleopatra Selene by her mother Cleopatra VII (Draycott, 2012), she also adds that this selection was intended to recall the glory of the Ptolemaic dynasty, and was mainly part of a larger strategy to revive the empire of Ptolemy Soter and his successor Ptolemy Philadelphos. Draycott concluded that the selection of the crocodile subsequently influenced the designs of Octavian's gold and silver AEGVPTO CAPTA coinage (Draycott, 2012). According to Draycott, Octavian was not an innovator. Ten years later, he used the same emblem of Egypt, once used to celebrate the Roman territories ceded to Egypt, to celebrate the opposite, the conquest of Egyptian territory by Rome (Draycott, 2012).

Certainly, the use of the crocodile by Octavian to symbolize Egypt resulted in the crocodile being subsequently adopted as such during the Roman Period.

If Crassus' coins were minted to mark the Romans ceding territories to Egypt, the following crocodilethemed issues fulfilled the opposite purpose, since they commemorate Rome's conquest of Egypt in 30 B.C. As a result, the illustration was consequently used on the gold and silver AEGVPTO CAPTA coinage of Octavian.

It is clear now that the decision of Octavian to place the image of a crocodile on the reverse of his coins is of special interest. In the first place, it introduces Octavian to the Romans as the victor over an exotic enemy. In addition, crocodiles were common in Greek and Roman art and were associated with danger (Lewis \& Llewellyn-Jones, 2018). As

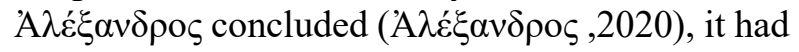
the added advantage of positioning MarkAntony and Cleopatra, the defeated couple, as a threat to Rome. This contributed to authorize the war of Octavian against his Roman counterpart. Thus, the crocodile helps to strengthen the concept that 
Octavian should be praised, not as the killer of his co-consul, but as the Roman Empire's savior.

In order to preserve the memory of the triumph of Octavian over the legendary figure of Antony, between 28 B.C. and 14 A.D., Octavian and his general Agrippa issued numerous Nîmes bronze coins with Augustus and Agrippa's back-to-back heads and the IMP-DIVI-F legend on the obverse and a crocodile chained to the palm, flanked on the reverse by the COL-NEM legend (Blanchet and Dieudonné, 1912, Sear, 2014, Rowan, 2018) (fig. $5)$. In 1535 , when the city was granted a new coat of arms by Francois I, based on the coin, the symbol became the emblem for Nîmes. In 1985, it was updated to the more current logo that it is today (Nash, 2021).

Juba II issued more silver denarii depicting a crocodile (fig. 6) during the reigns of Augustus and his successor Tiberius (Rocca, 2015). In 25 B.C, after assigning Juba II as king of Mauretania by Augustus, several silver denarii of Juba II featured a crocodile with inscriptions on the obverse (fig. 4) to honor his wife Cleopatra Selene (Roller, 2004), this might to revive her heritage as a descendant of the Ptolemies.

\subsection{Crocodiles Accompanying Egyptian Gods}

The representations of crocodiles were most frequently on coins issued in Egypt. Though numerous of Egyptian coins with crocodiles were minted by the Romans, few productions used this creature as the main feature. It seems that these examples are related to a minor classification (Vagi, 2015), the copper dichalkon, díx $\alpha \lambda \kappa o v$ (figs. $7,8,9$ ).

One of the interesting scenes of the crocodile on the dichalkon is that depicts him wearing the solar disk headdress (fig. 9), indicating his association with God Re and to ensure that the crocodile on this coin is not a regular crocodile, he is God Sobek-Re. Sobek identification with the sun-god Re, which started from the Middle Kingdom onwards, reflects Sobek position initially as his protector and subsequently as a solar deity (Galuzina, 2016). This association was strengthened during the Greco-Roman period. At the temple of Kom Ombo, a hymn describes Sobek-Rê as "the one who brings the Nile" or "the one who makes the Nile flow" (Koemoth, 2011).

The crocodile's most prominent appearance on Egyptian coins was as Nilus's consort, the god of the Nile River, the primary source of prosperity of
Egypt. Nilus is followed by the crocodile on the gold, silver and common metal coins minted by Hadrian in Rome (fig. 10) to commemorate his stay in Egypt in 130 A.D (Sear, 2002). Nilus, in this kind of coins, is usually depicted holding a cornucopia with a crocodile beneath or in front of him and sometimes a hippopotamus accompanied both of them. Koemoth suggested that the crocodile here may refer to Soknopaious/ Sobek-Hapi who personified the Nile and its flood (Koemoth, 2011). So, the representation of Nilus with the crocodile could resemble both the Nile and the real power over its inundation.

In addition to the regular types, crocodiles also appear on some exceptional Roman Egyptian coins (Vagi, 2015). For examples, sometimes crocodiles are held up high by gods as in the case of god Suchos-Kronos (fig. 11). Suchos-Kronos is a very interesting form appeared during the Hellenistic and Roman period, where Suchos, Sobek, was associated with the iconography of the Greek God Kronos. This form was found in many sanctuaries inside Egypt where Sobek was venerated such as in Tebtunis (Rondot, 1998). It was found, moreover, outside Egypt especially in Italy where Kronos was represented on coins, sculptures and gems holding a crocodile (Mastrocinque, 2011). Such presentations of Suchos-Kronos outside Egypt could indicate the presence of a possible cult dedicated to Sobek within the religious context of the Italian territory.

In other times parts of crocodiles were merged in fanciful compositions with other gods. For instance, with god Harpocrates (Hawass, \& Richards, 2007) as shown in the coin of Antoninus Pius (fig, 13), Harpocrates is depicted with his lower body in crocodile form as in coins of Trajan (fig. 12) and Hadrian (figs. 14) where the crocodile's head appeared as a pectoral decoration on a crowned Egyptian sphinx, which was also ornamented with an uraeus tail and a griffin upon its back.

\subsection{Coins with Roman Emperors on the Reverse}

Crocodiles also appeared in scenes with Emperors on the reverse of some roman coins such as Hadrian (Fig. 16) and Caracalla. After more than one century of the production of the golden AEGVPT CAPTA coin, Emperor Caracalla, in A.D. 215 issued gold and copper coins (fig. 17, 18) 
which might be the last appearance of Egyptian crocodiles on Roman coins. The coin represents the Egyptian goddess Isis kneeling before Caracalla, the emperor put his right foot on a crocodile. The representation of Isis kneeling and greeting the Emperor is a reference to the visit of Caracalla to Egypt in 215 A.D. The crocodile under his foot is likely a reference to Caracalla's ferocity actions and the slaughter of residents during his visit to Alexandria (Dunstan, 2010). Perhaps, Caracalla intended to revive the symbol of the domination of Rome over Egypt.

The representation of an Emperor with his foot over a crocodile is not unique it was famous and common in the Egyptian art. For instance, there is a stela, dated back to the Ptolemaic period, of Horus on crocodiles (fig. 15), stored in the Brooklyn Museum No. 60.73., where Horus is figured upon crocodiles. It is used to be interpreted as a defeated and trampled evil or enemy of the Table 1
Egyptians. On the contrary, the crocodile in the Roman coinage is Egypt itself, its symbol of power and fertility that were acquired by the Romans

\section{Methodology}

The examined sample consists of 15 coins which cover the period from late $1^{\text {st }}$ century B.C. to $3^{\text {rd }}$ century A.D. These coins were chosen based on the position of the crocodile on them, so that almost one or two models of the same type are represented to avoid repetition. The details of each coin were studied in terms of legends, the drawings on the obverse and reverse, the way in which the crocodile was depicted and positioned on the coin and the place and date of production. After that, all of the collected data were organized and tabulated (Table. 1 ) in order to be analyzed to reach the results

\section{Findings and discussion}

Details of the studied coins with various crocodile depictions

\begin{tabular}{|c|c|c|c|c|c|c|c|c|c|}
\hline Coin & Authority & $\begin{array}{l}\text { Materi } \\
\text { al }\end{array}$ & Obverse & Reverse & $\begin{array}{l}\text { Production } \\
\text { Place }\end{array}$ & Date & $\begin{array}{l}\text { Main } \\
\text { Scene }\end{array}$ & $\begin{array}{l}\text { With } \\
\text { God }\end{array}$ & $\begin{array}{l}\text { With } \\
\text { Emperor }\end{array}$ \\
\hline & $\begin{array}{l}\text { Marcus } \\
\text { Licinius } \\
\text { Crassus }\end{array}$ & Bronze & $\begin{array}{l}\text { Crocodile } \\
\text { standing } \\
\text { right }\end{array}$ & $\begin{array}{l}\text { Ship's prow } \\
\text { CRASS }\end{array}$ & Crete & $\begin{array}{l}\text { Circa } 37 \\
\quad \text { B.C } \\
\text { Ptolemai } \\
\text { c Period }\end{array}$ & $\sqrt{ }$ & $\mathrm{x}$ & $\mathrm{x}$ \\
\hline & Augustus & Gold & $\begin{array}{c}\text { Head of } \\
\text { Augustus } \\
\text { CAESAR.DI } \\
\text { VI.F.COS.V } \\
\text { II }\end{array}$ & $\begin{array}{l}\text { Crocodile standing } \\
\text { right } \\
\text { AEGVPT CAPTA }\end{array}$ & Pergamum? & 27 B.C & $\sqrt{ }$ & $\mathrm{x}$ & $\mathrm{x}$ \\
\hline & Augustus & Copper & $\begin{array}{l}\text { portraits of } \\
\text { both } \\
\text { Emperor } \\
\text { Augustus, } \\
\text { bare-headed, } \\
\text { and the } \\
\text { deceased } \\
\text { general } \\
\text { Agrippa } \\
\text { IMP/DIVIF }\end{array}$ & $\begin{array}{l}\text { chained crocodile } \\
\text { standing right }\end{array}$ & $\begin{array}{c}\text { Gaul, } \\
\text { Nemausus }\end{array}$ & $\begin{array}{l}\text { circa } 9 \text { to } \\
3 \text { B.C }\end{array}$ & $\sqrt{ }$ & $\mathrm{x}$ & $\mathrm{x}$ \\
\hline & $\begin{array}{l}\quad \text { Juba II } \\
\text { Cleopatra } \\
\text { Selene }\end{array}$ & Silver & $\begin{array}{c}\text { Diademed } \\
\text { head of Juba } \\
\text { II } \\
\text { REX IVBA }\end{array}$ & $\begin{array}{l}\text { Crocodile standing } \\
\text { left }\end{array}$ & Mauretania & $\begin{array}{l}25-24 \\
\text { B.C }\end{array}$ & $\sqrt{ }$ & $\mathrm{x}$ & $\mathrm{x}$ \\
\hline & Tiberius & Copper & $\begin{array}{l}\text { Bare head of } \\
\text { Tiberius }\end{array}$ & $\begin{array}{l}\underset{\text { right }}{\text { crocodile standing }} \\
\mathrm{L} \Delta \text {, below }\end{array}$ & Alexandria & $\begin{array}{l}17-18 \\
\text { A.D }\end{array}$ & $\sqrt{ }$ & $\mathrm{x}$ & $\mathrm{x}$ \\
\hline
\end{tabular}


W. F. I. Moussa. / IJHTH vol 15 issue 1 (2021) 17-29

\begin{tabular}{|c|c|c|c|c|c|c|c|c|c|}
\hline Coin & Authority & $\begin{array}{l}\text { Materi } \\
\text { al }\end{array}$ & Obverse & Reverse & $\begin{array}{l}\text { Production } \\
\text { Place }\end{array}$ & Date & $\begin{array}{l}\text { Main } \\
\text { Scene }\end{array}$ & $\begin{array}{l}\text { With } \\
\text { God }\end{array}$ & $\begin{array}{l}\text { With } \\
\text { Emperor }\end{array}$ \\
\hline & Claudius & Copper & $\begin{array}{c}\text { laureate } \\
\text { head of } \\
\text { Claudius } \\
\text { TIB K^AV }\end{array}$ & $\begin{array}{l}\text { crocodile standing } \\
\text { right } \\
\text { LI }\end{array}$ & Alexandria & $\begin{array}{l}49-50 \\
\text { A.D }\end{array}$ & $\sqrt{ }$ & $\mathrm{x}$ & $\mathrm{x}$ \\
\hline & Domitian & Copper & $\begin{array}{l}\text { Laureate } \\
\text { head of } \\
\text { Domitian }\end{array}$ & $\begin{array}{l}\text { crocodile standing } \\
\text { right with sun } \\
\text { headdress } \\
\text { L } \Delta \text {, above }\end{array}$ & Alexandria & $\begin{array}{l}84-85 \\
\text { A.D }\end{array}$ & $\sqrt{ }$ & $\mathrm{x}$ & $\mathrm{x}$ \\
\hline & Hadrian & Silver & $\begin{array}{l}\text { Bare head of } \\
\quad \text { Hadrian } \\
\text { HADRIAN } \\
\text { VS AVG } \\
\text { COS III P P }\end{array}$ & $\begin{array}{l}\text { Nilus reclining } \\
\text { right, holding reed } \\
\text { and Cornucopia. } \\
\text { Crocodile on right. } \\
\text { NILVS }\end{array}$ & Rome & $130-138$ & $\mathrm{x}$ & $\sqrt{ }$ & $\mathrm{x}$ \\
\hline & $\begin{array}{l}\text { Antonine } \\
\text { age }\end{array}$ & $?$ & $?$ & $\begin{array}{l}\text { the Egyptian } \\
\text { Kronos held aloft a } \\
\text { crocodile }\end{array}$ & $?$ & & $\mathrm{x}$ & $\sqrt{ }$ & $\mathrm{x}$ \\
\hline & Trajan & Bronze & $\begin{array}{l}\begin{array}{l}\text { Laureate } \\
\text { head of } \\
\quad \text { Trajan }\end{array} \\
\text { AYT } \\
\text { TPAIAN C- } \\
\text { EB GEPM } \\
\text { DAKIK }\end{array}$ & $\begin{array}{l}\text { Egyptian sphinx, } \\
\text { wearing composite } \\
\text { crown with } \\
\text { crocodile emerging } \\
\text { from chest } \\
\text { advancing right } \\
\text { LI }\end{array}$ & Alexandria & $\begin{array}{l}109-110 \\
\text { A.D }\end{array}$ & $\mathrm{x}$ & $\sqrt{ }$ & $\mathrm{x}$ \\
\hline & $\begin{array}{l}\text { Antoninus } \\
\text { Pius }\end{array}$ & Bronze & $\begin{array}{l}\text { Laureate } \\
\text { head of } \\
\text { Antoninus } \\
\text { Pius } \\
\text { MENE- } \\
\text { LAEITH }\end{array}$ & $\begin{array}{c}\text { Harpocrates of } \\
\text { Canopus as part of } \\
\text { a human } \\
\text { and part of a } \\
\text { crocodile) standing } \\
\text { left with his finger } \\
\text { to } \\
\text { mouth and holding } \\
\text { Cornucopiae }\end{array}$ & Alexandria & $\begin{array}{c}144-145 \\
\text { A.D }\end{array}$ & $\mathrm{x}$ & $\sqrt{ }$ & $\mathrm{x}$ \\
\hline & Hadrian & Bronze & $\begin{array}{c}\text { Laureate } \\
\text { head of } \\
\text { Hadrian } \\
\text { KAIC } \\
\text { TPAIAN } \\
\text { A } \triangle \text { PIANOC } \\
\text { CE }\end{array}$ & $\begin{array}{l}\text { Egyptian sphinx } \\
\text { with uraeus tail, } \\
\text { wearing composite } \\
\text { crown and } \\
\text { crocodile pectoral } \\
\text { walking on a } \\
\text { serpent; griffin } \\
\text { seated right on } \\
\text { sphinx's back } \\
\text { LIH }\end{array}$ & Alexandria & $\begin{array}{c}133-134 \\
\text { A.D }\end{array}$ & $\mathrm{x}$ & $\sqrt{ }$ & $\mathrm{x}$ \\
\hline & Hadrian & Copper & $\begin{array}{l}\text { Bare head of } \\
\text { Emperor } \\
\text { Hadrian } \\
\text { facing right } \\
\text { HADRIAN } \\
\text { VS AVG } \\
\text { COS III P P }\end{array}$ & $\begin{array}{l}\text { Hadrian, bare- } \\
\text { headed, in military } \\
\text { dress, standing } \\
\text { facing right, } \\
\text { holding a vertical } \\
\text { spear in his right } \\
\text { hand his left foot } \\
\text { on a crocodile } \\
\text { S C }\end{array}$ & Rome & $\begin{array}{c}130-138 \\
\text { A.D }\end{array}$ & $\mathrm{x}$ & $\mathrm{x}$ & $\sqrt{ }$ \\
\hline
\end{tabular}


W. F. I. Moussa. / IJHTH vol 15 issue 1 (2021) 17-29

\begin{tabular}{|c|c|c|c|c|c|c|c|c|c|}
\hline Coin & Authority & $\begin{array}{l}\text { Materi } \\
\text { al }\end{array}$ & Obverse & Reverse & $\begin{array}{l}\text { Production } \\
\text { Place }\end{array}$ & Date & $\begin{array}{l}\text { Main } \\
\text { Scene }\end{array}$ & $\begin{array}{l}\text { With } \\
\text { God }\end{array}$ & $\begin{array}{l}\text { With } \\
\text { Emperor }\end{array}$ \\
\hline & Caracalla & Copper & $\begin{array}{c} \\
\text { Laureate } \\
\text { head of } \\
\text { Caracalla } \\
\text { M AVREL } \\
\text { ANTONINV } \\
\text { S PIVS } \\
\text { AVG } \\
\text { GERM }\end{array}$ & $\begin{array}{c}\text { Caracalla, in } \\
\text { military dress, } \\
\text { standing with his } \\
\text { foot over a } \\
\text { crocodile, holding } \\
\text { vertical spear in } \\
\text { left hand and } \\
\text { extending right } \\
\text { hand to Isis, } \\
\text { advancing left, } \\
\text { holding corn-ears } \\
\text { in right hand and } \\
\text { sistrum in her left } \\
\text { hand } \\
\text { P M TR P XVIII } \\
\text { IMP III COS IIII P } \\
\text { P } \\
\text { S C }\end{array}$ & Rome & 215 A.D & $\mathrm{x}$ & $\sqrt{ }$ & $\sqrt{ }$ \\
\hline & Caracalla & Gold & $\begin{array}{c}\text { Laureate } \\
\text { head of } \\
\text { Caracalla } \\
\text { facing left } \\
\text { ANTONINV } \\
\text { S PIVS } \\
\text { AVG } \\
\text { GERM }\end{array}$ & $\begin{array}{c}\text { Caracalla standing } \\
\text { with his left, right } \\
\text { foot on crocodile, } \\
\text { Isis } \\
\text { P M TR P XVIII } \\
\text { COS IIII P P }\end{array}$ & Rome & 215 A.D & $\mathrm{x}$ & $\sqrt{ }$ & $\sqrt{ }$ \\
\hline
\end{tabular}

By analyzing the data tabulated in the previous table, we can find the following:

- All of the artifacts in this study are Roman and the crocodile appear on the reverse except the one of Crassus dated back to the Ptolemaic Period with a crocodile presented on the obverse.

- All bear depictions of a crocodile as an emblematic of Egypt.

- In all cases where the crocodile is the main figure on the obverse, however being watchful, it appeared laying at rest on its stomach, with a snout partly raised and standing right, except the coin of Juba II where the crocodile is standing to the left, may be for a strategic purpose.

- Egyptian Crocodiles usually appear, as the main design, on the reverse of coins minted in Egypt, the Eastern Mediterranean, Mauretania, Nemausus and Rome.

- AEGYPTO CAPTA coins were firstly issued in 28 B.C. in silver denarii in Italy and in the Eastern Mediterranean followed by a small issue of gold aurei in 27 B.C. of the same type during the time Octavian who had begun to use the name Augustus, a sign may be to mark the start of the long reign of Rome's first Emperor.

- Crocodiles appear most frequently on coins produced in Egypt, as would be predicted. While numerous Egyptian coins with crocodiles were struck by the Romans, very few use this animal as the main feature, it always appears accompanying a god (mainly Nilus and Harpocrates) or the Emperor himself and in some cases both as in (figs, $17 \& 18)$.

- With the exception of the AEGYPTO CAPTA coinage, examples of crocodiles as the primary motif are limited to the copper dichalkon, a minor denomination and more probably have been struck in tiny amounts.

- Hadrian issued lots of coins with Nilus accompanying crocodiles on gold, silver and base metal in Rome to commemorate his visit to Egypt.

In addition to the regular themes, crocodiles also depicted on few exceptional Roman Egyptian coins. In some examples, the god Kronos hold them aloft; while in other times parts of the crocodiles' bodies are utilized in fictional depictions of gods. 


\section{Conclusion}

The Roman coins studied here were based on the Ptolemaic framework, established in 30 B.C. by Octavian after the possession of Egypt. Developed, correlated and controlled along with Roman coinage, by the following Emperors specially Hadrian and Caracalla who likely intended to recall the glory of their first Emperor. The sample proved that the existence of the crocodile was not limited to Egypt. Within the Hellenistic Roman world, the Nile crocodile witnessed a great popularity in the foreign lands especially in the roman provinces. His existence took many forms which reflects political, artistic or religious aspects.

On the coins of the Gaul, Nemausus stroked under Augustus, the crocodile was bound to a palm tree as a symbol of Egypt's subjugation under Roman power. It is also prominent, with open mouth and the historical legend AEGVPT CAPTA on silver and gold coins of Augustus. On other coins the crocodile depicted at the feet of the recumbent Nilus. However, being identified rarely as the main feature, but among those limited coins, with crocodiles on the reverse as the main figure, it sometimes appeared as Sobek-Re. In later image he accompanied the emperors probably to evoke their role in controlling Egypt.

The symbolism of the crocodile outside Egypt reached its peak during the reign of Hadrian, either as a symbol of Egypt itself or to revive the symbol of the domination of Rome over Egypt.

The study revealed that the existence of the crocodile images on the Roman coinage might be assigned to the following interpretive: a) political based celebrations related to Egypt's possession, b) religious subjects associated with the cult of certain Gods as; Nilus and Harpocrates, c) to express the force of the Emperor to suppress and control Egypt

\section{References}

Ahmad Nizar, N. N., Ali, M. E., Hossain, M. M., Sultana, S., \& Ahamad, M. N. U. (2018). Double gene targeting PCR assay for the detection of Crocodylus porosus in commercial products. Food Additives \& Contaminants: Part A, 35(6), 10381051.

Amandry, M., Burnett, A., \& Ripollés, P. P. (2019). Roman provincial coinage. British Museum Press.

Aristotle's History of Animals, 9.1.

Bagnall, R. S. (2013). The encyclopedia of ancient history. Malden, MA: Wiley-Blackwell.
Barret, C. E. (2017). Egypt in Roman Visual and Material Culture. Oxford Handbooks Online in Classical Studies.

BLANCHET A., DIEUDONNÉ A. (1912) Manuel de Numismatique Française, t.1 Monnaies frappées en Gaule depuis les origines jusqu'à Hugues Capet, Picard A., France

Bland, R., \& Loriot, X. (2010). Roman and Early Byzantine gold coins found in Britain and Ireland. Royal Numismatic Society Special Publication, 46.

Bresciani, E. (2005). Sobek, Lord of the Land of the Lake. Divine Creatures: Animal Mummies in Ancient Egypt, The American University in Cairo Press, Cairo, 199-206.

Britannica, E. (1997). The New Encyclopaedia Britannica: Micropaedia: Knowledge in Depth: Vol 15. Encyclopaedia Britannica.

Brogan, T. M., \& Vogeikoff-Brogan, N. (2006). Crete: Historical Times. Archaeology of the Aegean Islands, 410-431.

Bunson, M. (2014). Encyclopedia of the Roman empire. Infobase Publishing.

Burns, A. R. (2013). Money and monetary policy in early times. Routledge.

Campbell, G. (Ed.). (2007). The Grove Encyclopedia of Classical Art and Architecture: Macedonia to Zygouries (Vol. 2). Oxford University Press, USA.

Crump, M. (2021). Eye of Newt and Toe of Frog, Adder's Fork and Lizard's Leg. University of Chicago Press.

Cunningham, S. W. (2015). Spatial and genetic analyses of Africa's sacred crocodile: Crocodylus suchus.

D. Vagi, Crocodiles on Roman coins familiar as the emblem of Egypt https://www.coinworld.com/news/preciousmetals/crocodiles-on-roman-coins-familiar-as-theemblem-of-egyptian-province.html (15 Feb 2015). Accessed 31 Jan 2021

Draycott, J. (2012, January). The symbol of Cleopatra Selene: reading crocodiles on coins in the late Republic and early Principate. In Acta Classica: Proceedings of the Classical Association of South Africa (Vol. 55, No. 1, pp. 43-56). Sabinet.

Dunstan, W. E. (2010). Ancient Rome. Rowman \& Littlefield Publishers.

Ermatinger, J. W. (2018). The Roman Empire [2 volumes]: A Historical Encyclopedia (Empires of the World) (Illustrated ed.). ABC-CLIO.

Galuzina, M. (2016). The God Sobek in Ptolemaic and Roman Times. A Confrontation of the Cult of Sobek in Krokodilopolis and Kom Ombo.

Grigg, G. (2015). Biology and evolution of crocodylians.

Hamilton, H. C. (Ed.). (1854). The geography of Strabo (Vol. 1). HG Bohn.

Hawass, Z., \& Richards, J. (2007). The Archaeology and Art of Ancient Egypt: Essays in Honor of David B. 
O'Connor (2 Volume Set) (Cahier No. 36 ed.). American University in Cairo Press.

Hekkala, E., Shirley, M. H., Amato, G., Austin, J. D., Charter, S., Thorbjarnarson, J., ... \& Blum, M. J. (2011). An ancient icon reveals new mysteries: mummy DNA resurrects a cryptic species within the Nile crocodile. Molecular ecology, 20(20), 4199-4215.

Hill, G. F. (1899). A handbook of Greek and Roman coins (Vol. 4). Macmillan and Company, limited.

Hingley, R. (2004). Becoming Roman, Writing Latin? Literacy and Epigraphy in the Roman West. Edited by AE Cooley. Journal of Roman Archaeology Supplementary Series 48. Journal of Roman Archaeology, Portsmouth, RI, 2002. Pp. 192, illus. ISBN 188782948 2. Britannia, 35, 352-353.

Ikram, S. (2015). Divine creatures: animal mummies in ancient Egypt. the American University in Cairo press.

Koemoth, PP (2011). Crown Souchos to celebrate the return of the flood. In Isis on the Nile. Egyptian Gods in Hellenistic and Roman Egypt (pp. 257289). Brill.

Lewis, S., \& Llewellyn-Jones, L. (2018). The culture of animals in Antiquity: A sourcebook with commentaries. Routledge.

Lomas, K. (2018). The rise of Rome: from the Iron Age to the Punic Wars. Harvard University Press.

Manning, J. G. (2003). Land and power in Ptolemaic Egypt: the structure of land tenure. Cambridge University Press.

Marginesu, G. (Ed.). (2019). Annuario della Scuola Archeologica di Atene e delle Missioni Italiane in Oriente. Supplemento 2. Studi sull'economia delle technai in Grecia dall'età arcaica all'ellenismo (Vol. 2). SAIA-Scuola Archeologica Italiana di Atene.

Mastrocinque, A. (2011). Kronos, Shiva, \& Asklepios: studies in magical gems and religions of the Roman Empire. Transactions of the American Philosophical Society, 101(5), i-130.

Mastrocinque, A. (2011). Kronos, Shiva, \& Asklepios: studies in magical gems and religions of the Roman Empire. Transactions of the American Philosophical Society, 101(5), i-130.

Metcalf, W. E. (Ed.). (2012). The Oxford handbook of Greek and Roman coinage. Oxford University Press.

Molcho, M. (2014). Crocodile breeding in the crocodile cults of the Graeco-Roman Fayum. The Journal of Egyptian Archaeology, 100(1), 181-193.

Murray M. A. 1957, The Splendour that was Egypt, New York.

Nash, S. (2021, February 8). Nîmes - Romans, Gastronomy and Crocodiles. Archaeology Travel. https://archaeology-travel.com/france/nimesromans-gastronomy-and-crocodiles/

Potter, D. (2019). The Origin of Empire: Rome from the Republic to Hadrian. Harvard University Press.
Robinson, E. S. G. (1927). A catalogue of Greek coins in the British Museum-Cyrenaica (BMC). London.

Rocca, S. (2015). Herods Judaea: A Mediterranean state in the classical world. Eugene, OR: Wipf \& Stock.

Roller, D. W. (2004). The world of Juba II and Kleopatra Selene: royal scholarship on Rome's African frontier. Routledge.

Rondot, V. (1998). Min maître de Tebtynis. Egyptian Religion. The Last Thousand Years. Studies Dedicated to the Memory of Jan Quaegebeur, 1, 241-253.

Rowan, C. (2018). From Caesar to Augustus (c. 49 BCAD 14): Using coins as sources. Cambridge University Press.

Saint-Hilaire, É. G. (1807). Description de deux crocodiles qui existent dans le Nil, comparés au crocodile de Saint-Domingue. Muséum National d'Histoire Naturelle.

Schmitz, A., Mansfeld, P., Hekkala, E., Shine, T., Nickel, H., Amato, G., \& Böhme, W. (2003). Molecular evidence for species level divergence in African Nile crocodiles Crocodylus niloticus (Laurenti, 1786). Comptes Rendus Palevol, 2(8), 703-712.

Sear, D. (2002). Roman Coins and Their Values, Vol II, The Accession of Nerva to the Overthrow of the Severan Dynasty AD 96 - AD 235 (Millenium ed.). Spink Books.

Sear, D. (2014). Roman Coins and Their Values Volume 5 (Vol. 5). Spink \& Son, Ltd.

Stevenson, S. W. (1889). A Dictionary of Roman Coins, republican and imperial. G. Bell and Sons.

Sutherland, C. H. V. (2018). Roman Imperial Coinage. Volume I (Vol. 1). Spink Books.

Sutherland, C. H. V. (2018). Roman Imperial Coinage. Volume I (Vol. 1). Spink Books.

Svoronos, J. N. (1904). Ta Nomismata tou kratous tōn Ptolemaiōn I-III.

Vagi.D. (2015, February 15). Crocodiles on Roman coins familiar as the emblem of Egypt. CoinWorld. https://www.coinworld.com/news/preciousmetals/crocodiles-on-roman coins-familiar-as-theemblem-of-egyptian-province.html. Accessed 31 Jan 2021.

Vliet, K. A. (2020). Alligators: the illustrated guide to their biology, behavior, and conservation. JHU Press.

Vogeikoff-Brogan, N. (2015). Mochlos III: The Late Hellenistic Settlement: The Beam-Press Complex. INSTAP.

Zecchi, M., \& Zecchin, M. (2010). Sobek of Shedet: the crocodile god in the Fayyum in the dynastic period. Tau.

'A $\lambda \dot{\varepsilon} \xi \alpha v \delta \rho o \varsigma$. (2020). The crocodile as a symbol of Egypt on a victory coin of Augustus ANCIENTCOINS.MARKET. Ancientcoins. https://ancientcoins.market/the-crocodile-as-a- 
symbol-of-egypt-on-a-victory-coin-of-augustus/.

Accessed: 23/1/2021

\section{Figure}

Fig. 1

Early depiction of the Egyptian crocodile as a God.

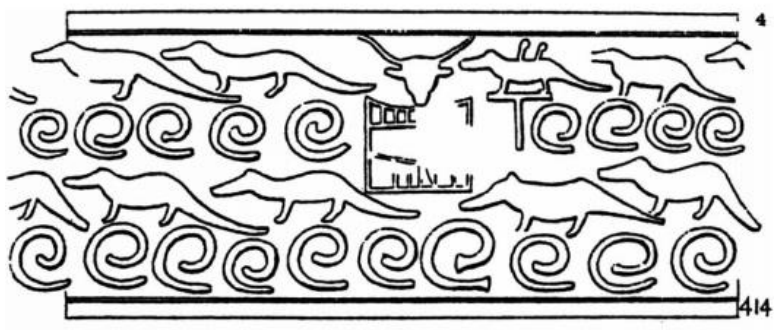

F. P.

Zecchi, 2010, fig.2

Fig. 3

A crocodile on the obverse of Crassus bronze Roman coin, 37 B.C.
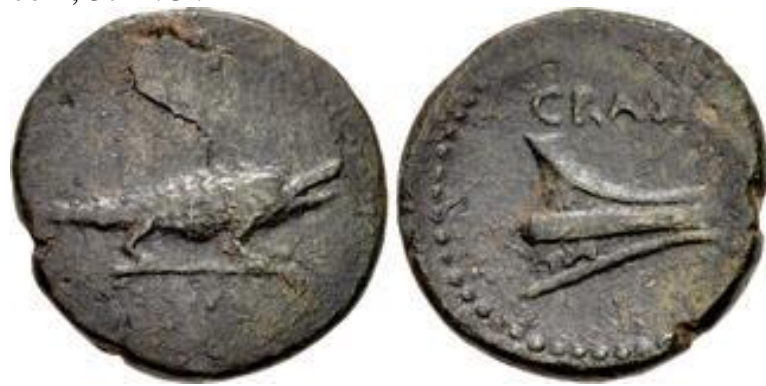

Marginesu, Ed, 2019, fig. 9

Fig. 5.

Copper coin of Nemausus, Gaul, circa 9 to 3 B.C
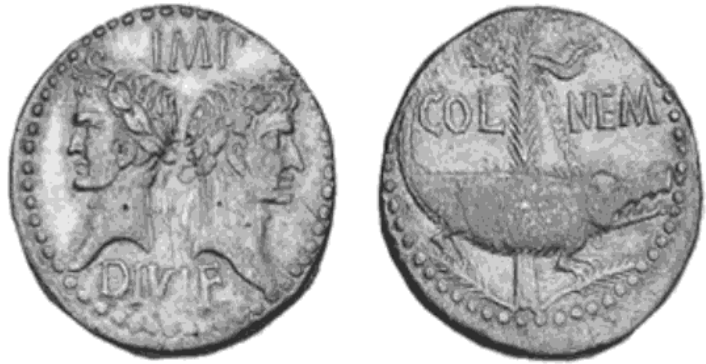

Sear, 2014, fig. 1730

Fig. 7

Dichalkon of Alexandria with bare head of Tiberius
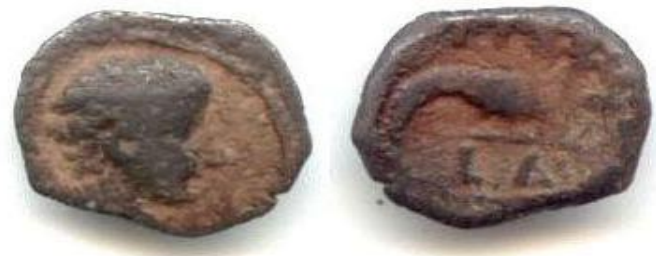

https://www.wildwinds.com/coins/sear5/s1780.html
Fig. 2

Bronze “Aes Rude," from Italy

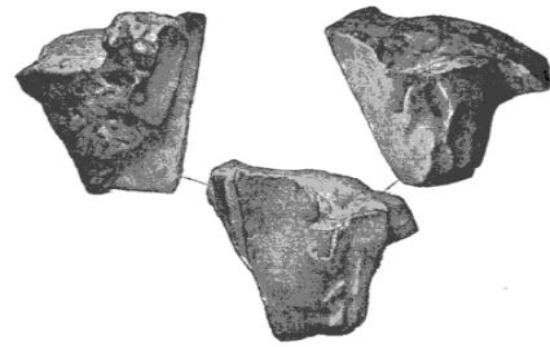

Hill, 1899, fig.9

Fig. 4

The crocodile as a symbol of Egypt on a victory gold coin of Augustus

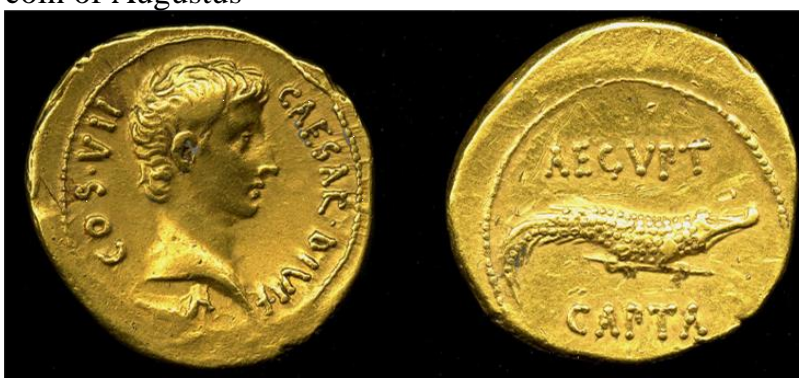

British Museum, 1897,0604.4

Fig. 6

Silver denarius of king juba II
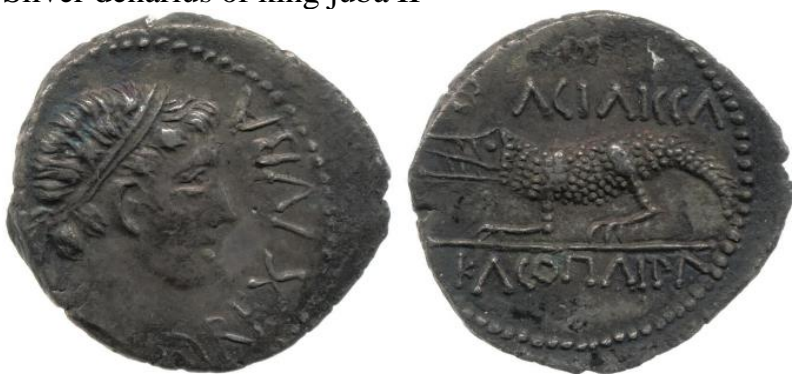

British Museum, 1850,0807.2

Fig. 8

Claudius Dichalkon of Alexandria
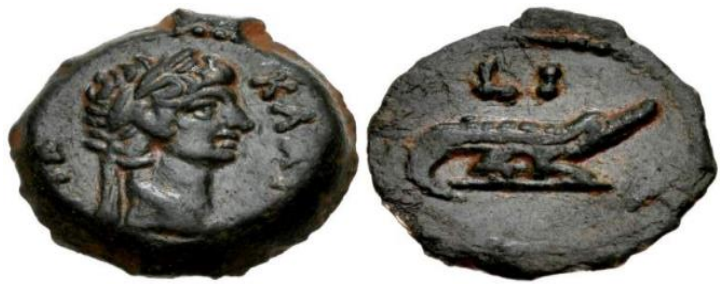

https://rpc.ashmus.ox.ac.uk/coins/1/5178 
Fig. 9

Laureate head of Domitian
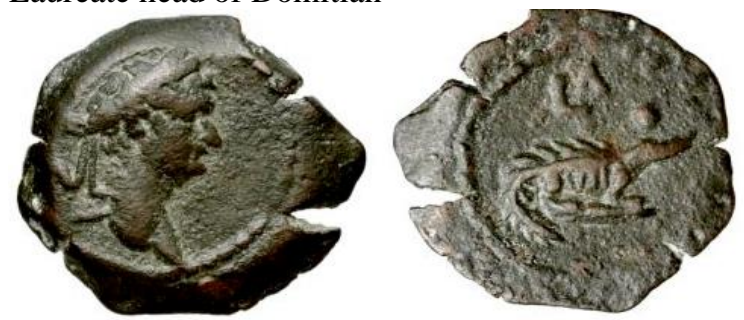

https://rpc.ashmus.ox.ac.uk/coins/2/2746

Fig. 11.

Alexandrian coin of Antonine age, representing the Egyptian Kronos. Drawing by R. Kotansky

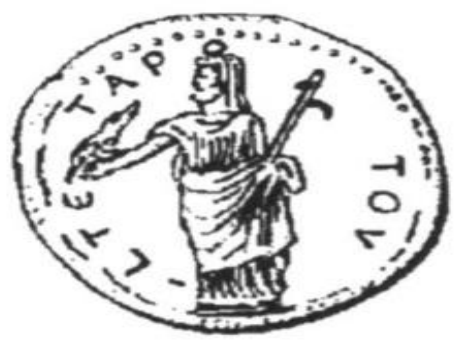

Mastrocinque, 2011, fig. 1.3

Fig. 13

Antoninus Pius
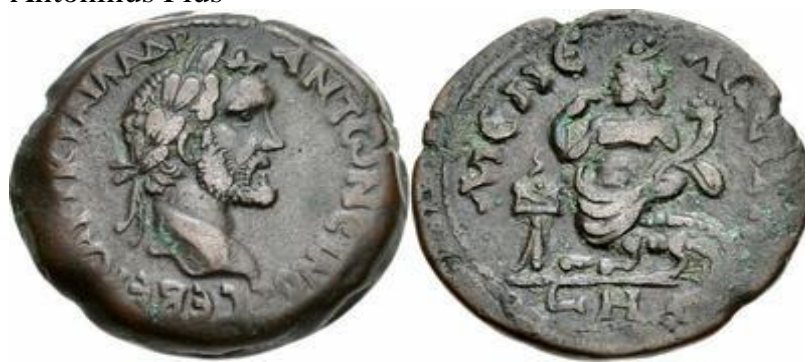

https://www.wildwinds.com/coins/greece/egypt/alexan dria/i.html

Fig. 15

Magical stelae of Horus on the Crocodiles, Ptolemaic Period, $3^{\text {rd }}$ century B.C.

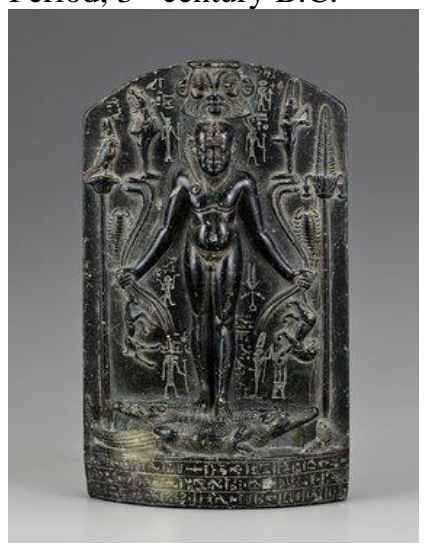

Brooklyn Museum No. 60.73.
Fig. 10

Bare head of Emperor Hadrian.
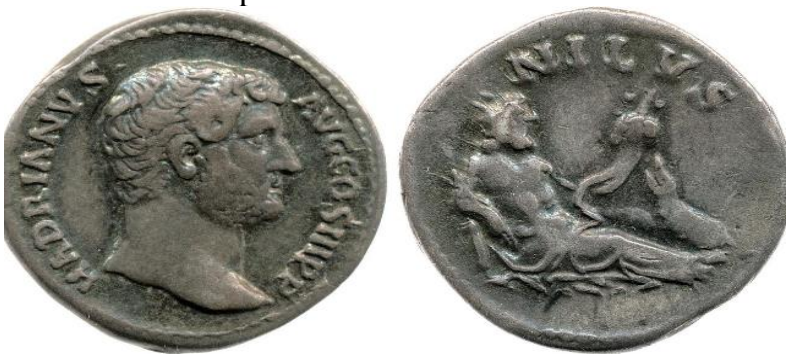

British Museum, R.12332

Fig. 12

Trajan drachm of Alexandria

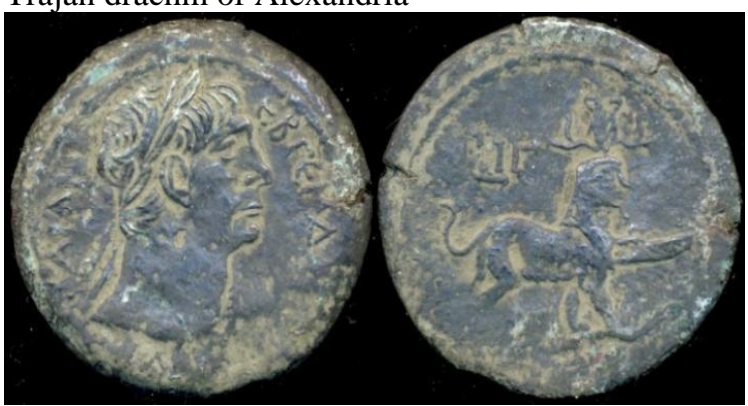

Amandry, et al., 2019, 4432.3A

Fig. 14

Hadrian AE Drachm of Alexandria.
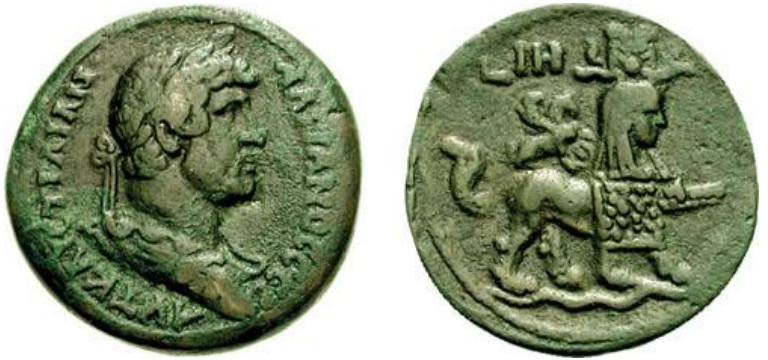

https://www.wildwinds.com/coins/greece/egypt/alexan dria/i.html

Fig. 16

Copper alloy coin with bare head of Hadrian
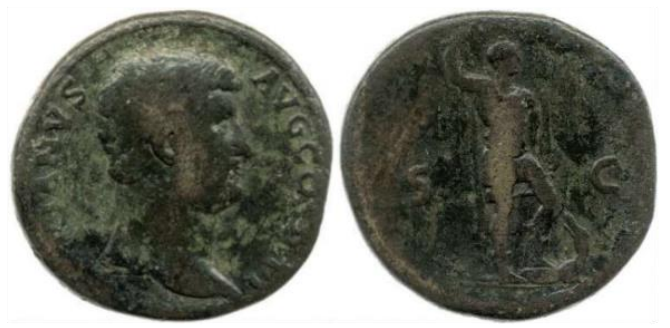

British Museum, R.9089 
Fig 17.

Copper alloy coin. Minted in: Rome, Caracalla

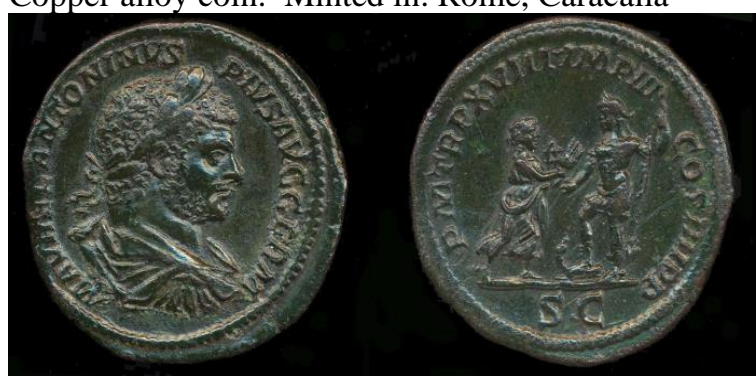

British Museum, 1872,0709.786
Fig. 18.

Gold Aureus of Caracalla

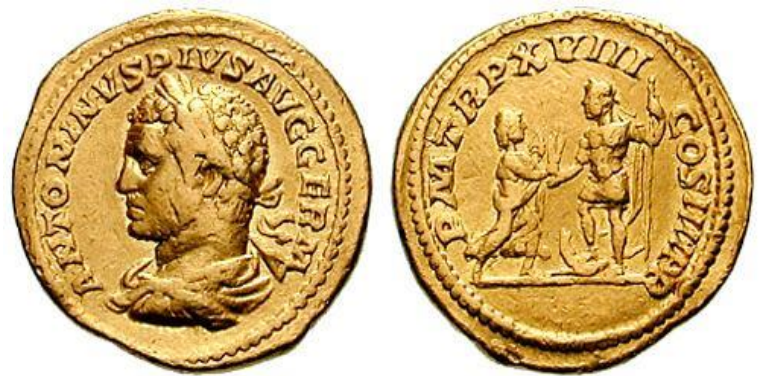

https://www.wildwinds.com/coins/sear5/s6715.html\#R IC_0257b 